\title{
PROPOSTAS PARA SUBSIDIAR UM PLANO DE AÇÕES EDUCATIVAS ÀS COMUNIDADES QUE UTILIZAM DIRETAMENTE O LAGO BOLONHA, BELÉM (PA)
}

Antônio Carlos Ribeiro Araújo Júnior ${ }^{1}$

RESUMO: Há de se pensar, quais fatores condicionam uma Educação Ambiental (EA) consciente no seio da sociedade e qual educação ambiental se torna importante ser aplicada na conjuntura brasileira em âmbito global e em nosso caso em âmbito local, no lago Bolonha. Neste sentido a discussão empreendida sobre educação ambiental foi desenvolvida com base em leituras acerca da temática e análises de como as populações próximas ao lago Bolonha podem, com o auxílio do poder público, desenvolver atividades que venham a contribuir para a minimização de eventuais impactos ambientais sobre a Área de Proteção Ambiental de Belém (APA Belém).

Palavras-chave: Educação Ambiental; Lago Bolonha; Ações Educativas.

${ }^{1}$ Graduado em Geografia (lic/bach) e mestrando do Programa de Pós-Graduação em Geografia da UFPA. Professor Assistente do Departamento de Geografia da Universidade Federal de Roraima (UFRR). E-mail: aj_geo@hotmail.com.

Revbea, Rio Grande, V. 8, № 1:50-67, 2013. 


\section{INTRODUÇÃO}

O Estado do Pará possui uma área de 1.253.164 Km² e 144 municípios que em sua maioria estão localizados às margens de cursos d'água. Tal fato torna-se preocupante se for levado em consideração o fato de que segundo Paiva et. al. (2004) mais de $98 \%$ da população paraense não dispõem de sistema de coleta de esgoto, lançando os seus efluentes domésticos "in natura" nos rios e igarapés.

A localização urbana, a elevada densidade demográfica e a presença de residências sem a mínima infraestrutura de saneamento próximo a corpos d'água tem como consequência a descarga de esgotos domésticos e industriais, o que ocasiona um elevado grau de impacto no ambiente.

A ação antropogênica nos ecossistemas de águas costeiras, estuarinas ou em ambientes de água doce, como os mananciais de abastecimento de água da RMB, nos dizeres de Paiva et. al. (2004), proporciona uma resposta rápida dos organismos fitoplanctônicos, ocasionando alterações em sua composição e biomassa.

Fragmentando-se o habitat são geradas mudanças nas condições ecológicas causando perda da biodiversidade, levando a sociedade a buscar na ciência soluções para lidar com problemas ambientais complexos (PAIVA et. al. 2004). Pelo fato de a ciência não ter respostas sanatórias para todo e qualquer tipo de interferência antrópica no meio natural, torna-se claramente necessário conservar os recursos naturais e compreender as implicações do manejo desses recursos e impactos estressantes.

Nesse ínterim, o município de Belém localizado na área de influência do estuário Guajarino, parte integrante de outro maior, o Golfão Marajoara situado na foz conjunta dos rios Amazonas, Tocantins, Pará e outros de menor extensão, tendo como elemento hídrico principal a baia do Guajará localizada em frente a cidade de Belém, prolongando-se até a llha do Mosqueiro, onde se encontra com a baia do Marajó (NASCIMENTO, 1995), possui uma interessante área de estudo, sua fonte de abastecimento hídrico.

O sistema hidrográfico dos Mananciais do Utinga é formado pela bacia hidrográfica do Murutucum (Figura 1), que integra a bacia do rio Guamá

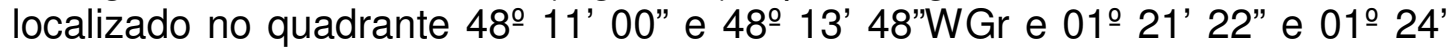
54" S (FEITOSA, 1994).

O lago Bolonha possui uma área de $577.127 \mathrm{~m}^{2}$ e volume d'água de aproximadamente $1.954 .000 \mathrm{~m}^{3}$. Localiza-se no Distrito Administrativo do Entroncamento (DAENT), além de apresentar, segundo leitura da planta DAENT (parte I), elaborada pela Prefeitura Municipal de Belém no ano de 2008, ligação "natural” com o rio Guamá por meio do igarapé do Murutucu (figura 1), além de apresentar em sua porção norte-noroeste e norte-nordeste ampla ocupação urbana (Figura 2). 


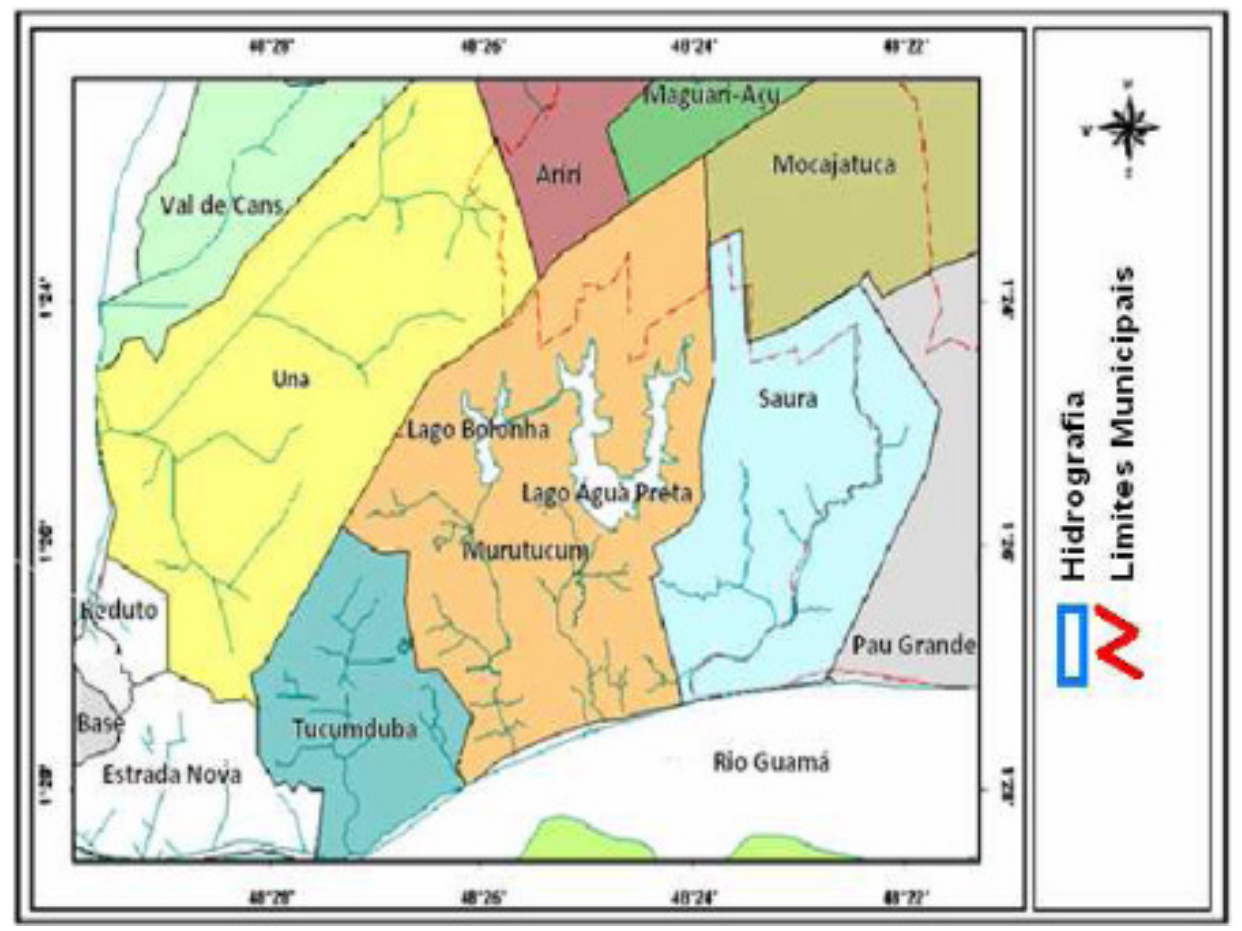

Figura 1: Bacia hidrográfica dos lagos Bolonha e Água Preta. Fonte: SECTAM (2006 apud SODRÉ, 2007).

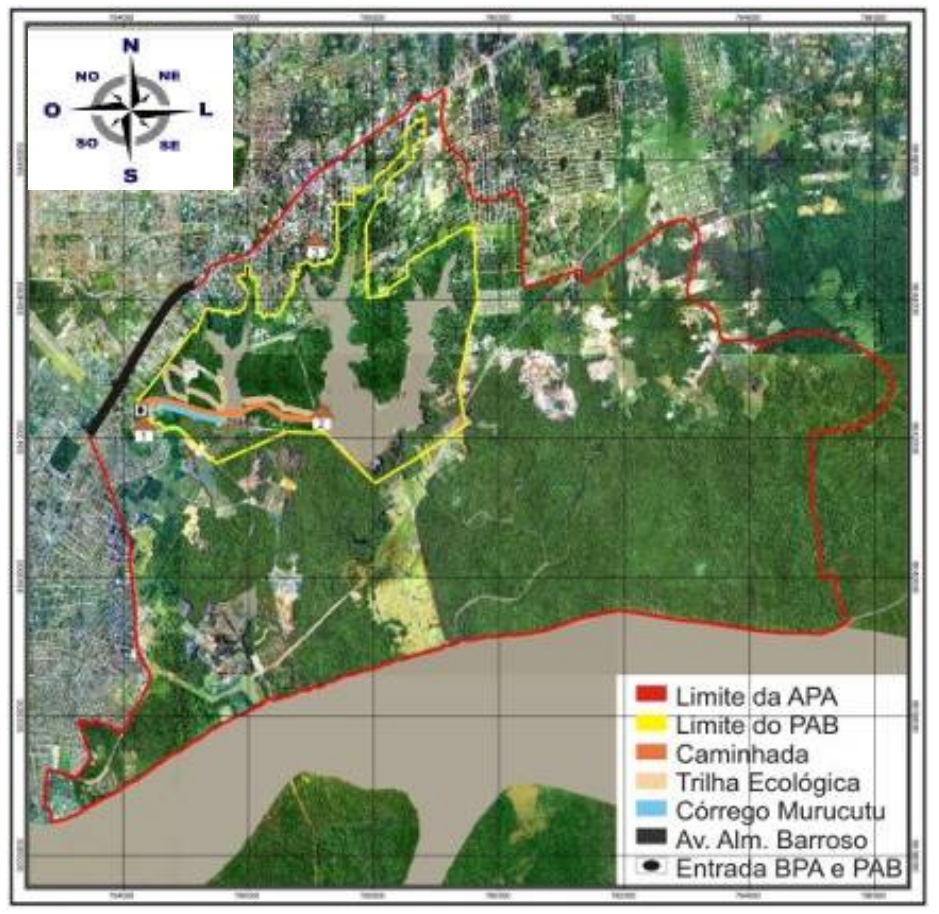

Figura 2: Limite da Área de Proteção Ambiental (APA) em vermelho e limite do Parque Ambiental de Belém (PAB) antigo Parque Ambiental de Belém (PAB). 
A Área de Proteção Ambiental de Belém se deve ao fato de esta abrigar a fonte de abastecimento de água de toda a Região Metropolitana de Belém (RMB), os lagos Bolonha e Água Preta, além de guardar um ambiente ameno e contemplativo com atrativos turísticos (caso das ruínas do Murutucu e sua história). Para tanto, a construção de muros ao redor da APA parece constituir método ortodoxo e pouco eficaz para se evitar a degradação deste ambiente.

Incorre-se então a procedimentos imateriais para construção e consolidação de alternativas para minimização de agravos contra o lago Bolonha e aí se chega a aplicação de métodos educacionais com o intuito de conscientizar ambientalmente os usuários de determinado espaço a conserválo.

Como se sabe a educação constitui uma arena, um espaço social que abriga uma diversidade de práticas de formação de sujeitos. A afirmação desta diversidade é produto da história social do campo educativo, no qual concorrem diferentes atores, forças e projetos na disputa pelos sentidos da ação educativa (CARVALHO, 2004).

Argumenta-se que a ideia de educação inclui a educação ambiental (EA), mas dificilmente se poderá reduzir toda a diversidade dos projetos educativos a uma só ideia geral e abstrata de educação. O que se arrisca apagar, segundo Carvalho (2004), sob a égide de uma educação ideal desde sempre ambiental, são as reivindicações de inclusão da questão ambiental, a qual sinaliza para o reconhecimento da importância de uma EA na formação dos sujeitos contemporâneos.

A ausência de serviços de saneamento básico, principalmente em países do mundo em vias de desenvolvimento, tem sido responsável por graves problemas de saúde pública que prejudicam a força de trabalho, causam a perda de muitas vidas e contribuem grandemente para agravamento de problemáticas concernentes ao meio ambiente.

Mesmo o Estado se fazendo presente, por meio de ações que venham a mitigar problemas socioambientais como a deposição de lixo (orgânico ou inorgânico) ou escoamento de efluentes domésticos em locais inapropriados, a internalização incutida nos agentes sociais não favorece uma práxis ${ }^{2}$, a qual esteja atrelada à idealização daquele que seria o sujeito educado ambientalmente, muito por conta das condições de vida do indivíduo como também da assistência irregular ou inexistente atuação do poder público.

Há de se pensar, para tanto, quais fatores condicionam uma Educação Ambiental (EA) consciente no seio da sociedade e qual educação ambiental se torna importante ser aplicada na conjuntura brasileira em âmbito global e em nosso caso em âmbito local, no lago Bolonha.

Neste sentido a discussão empreendida sobre EA foi desenvolvida com base em leituras acerca da temática e análises de como as populações

\footnotetext{
${ }^{2}$ Entendida como o ato filosoficamente pensado.
} 
próximas ao lago Bolonha podem, com o auxílio do poder público, desenvolver atividades que venham a contribuir para a minimização de eventuais impactos ambientais sobre a APA Belém.

\section{ELEMENTOS DE EDUCAÇÃo AMBIENTAL: UMA BREVE CONTEXTUALIZAÇÃO}

Para este trabalho o entendimento tido por EA é o nome que historicamente se convencionou dar às práticas educativas relacionadas à questão ambiental. Coadunando com Layrargues (2004), "Educação Ambiental" designa uma qualidade especial que define uma classe de características que juntas permitem o reconhecimento de sua identidade diante de uma Educação que antes não era ambiental.

Porém, é importante pensar quais formas de pensamento (classificações e denominações) explicitam as concepções que preenchem de sentido as práticas e reflexões pedagógicas relacionadas à questão ambiental, uma vez que aparentemente não se faz mais EA. Dizer que se trabalha com educação ambiental, apesar do vocábulo conter em si os atributos mínimos cujos sentidos diferenciadores da Educação (que não é ambiental) são indiscutivelmente conhecidos, parece não fazer mais plenamente sentido (LAYRARGUES, 2004).

Tal assertiva tem como reforço o fato de que uma gama de nomenclaturas (Alfabetização Ecológica, Ecopedagogia, Educação Ambiental Crítica, Transformadora ou Emancipatória, Educação no Processo de Gestão Ambiental, etc.) aparece dando novos significados à EA, tornando-a cada vez mais específica a uma determinada realidade. Não se quer aqui esclarecer o significado de cada uma das nomenclaturas citadas, mas mostrar possíveis formas de aplicação educacional sobre o ambiente, esclarecendo as formas de atuação do poder público, bem como o papel da sociedade como um todo.

Neste sentido, de acordo com o artigo 225 da Constituição Federal de 1988 tem-se por objetivo a defesa e preservação pelo Poder Público e pela coletividade de um bem público (o meio ambiente ecologicamente equilibrado), cujo modo de apropriação dos seus elementos constituintes, pela sociedade, pode alterar as suas propriedades e provocar danos ou ainda produzir riscos que ameacem a sua integridade (QUINTAS, 2004).

A segurança ao bom viver da coletividade também deve ser assegurada, juntamente com o proporcionar de uma boa qualidade de vida, dando à coletividade meios de utilizar os recursos naturais de forma a satisfazer suas necessidades básicas. O que se percebe, no entanto, é o uso e apropriação dos recursos não harmoniosamente, estando envolvidos interesses, os quais podem culminar em conflitos (potenciais e explícitos), seja por conta da manutenção do uso (racional ou não) ou simples defesa do espaço físiconatural. 
Segundo Quintas (2004), entre a necessidade de assegurar o direito ao meio ambiente ecologicamente equilibrado, como bem de uso comum da população e a definição do modo como devem ser apropriados os recursos ambientais na sociedade, é que o processo decisório sobre a sua destinação opera. Assume aí um importante papel a EA como atenuante de processos danosos ao meio ambiente, o qual a sociedade é componente indissociável.

A Constituição Federal de 1988, através do Parágrafo primeiro do artigo 225, responsabiliza o Poder Público (e somente a ele) por sete incumbências, mesmo impondo a este e à coletividade a obrigação por sua defesa e preservação, podendo as incumbências ser visualizadas no Quadro 1.

Quadro 1: A fazeres do Poder Público de acordo com as incumbências do parágrafo primeiro do artigo 225 da Constituição Federal de 1988.

\begin{tabular}{|c|l|}
\hline $\begin{array}{c}\text { Das sete } \\
\text { incumbências }\end{array}$ & \multicolumn{1}{|c|}{ A fazeres do Poder Público } \\
\hline $\begin{array}{c}\text { Quatro (I, II, III } \\
\text { e VII) }\end{array}$ & $\begin{array}{l}\text { Direcionam a ação do Poder Público para defesa e proteção de processos } \\
\text { ecológicos essenciais, ecossistemas, patrimônio genético, flora e fauna } \\
\text { utilizando diferentes estratégias (preservar, restaurar, manejar, fiscalizar, } \\
\text { criar áreas protegidas); }\end{array}$ \\
\hline Duas (IV e V) & $\begin{array}{l}\text { Corroboram para a prevenção de danos e avaliação de riscos ambientais, } \\
\text { decorrentes da realização de obras e atividades potencialmente } \\
\text { degradadoras, e da produção e circulação de substâncias perigosas; }\end{array}$ \\
\hline Uma (VI) & $\begin{array}{l}\text { Voltada para a criação de condições para coletividade cumprir o seu dever } \\
\text { de defender e proteger "o meio ambiente ecologicamente equilibrado para } \\
\text { as presentes e futuras gerações", por meio da promoção da educação } \\
\text { ambiental. }\end{array}$ \\
\hline
\end{tabular}

Fonte: Adaptado de Constituição Federal de 1988.

Para Quintas (2004), estas incumbências estabelecem as bases legais para o ordenamento da prática da gestão ambiental no Brasil pelo Poder Público, seja pela validação de dispositivos anteriores a Constituição de 1988, seja pela promulgação de novos. No tópico seguinte (ações educativas e o lago Bolonha: propostas de educação ambiental) deste trabalho será tratada a questão do Artigo 3ำ do Decreto Estadual o 1.552 de 03 de maio de 1993 e como este entra em consonância com o Artigo 225 da Constituição federal de maneira ativa.

No entanto, percebe-se que a intervenção individual e coletiva Quadro 2, de modo qualificado, tanto na gestão do uso dos recursos ambientais quanto na concepção e aplicação de decisões que afetam a qualidade do meio ambiente, seja ele físico-natural ou construído (IBAMA, 1995), perpassa por decisões e ações tomadas nos campos de tensionamento dos mais diversos agentes sociais envolvidos em processos, os quais façam uso de recursos naturais. 
Quadro 2: Principais fatores que comprometem a qualidade das águas dos mananciais de Belém

\begin{tabular}{|l|l|}
\hline Uso residencial & $\begin{array}{l}\text { Modificações locais devido à destruição da } \\
\text { cobertura vegetal para construção (casas, } \\
\text { ruas etc); destino dos despejos e líquidos; } \\
\text { contaminação bacteriana. }\end{array}$ \\
\hline Uso recreacional & $\begin{array}{l}\text { Contaminação bacteriana das águas } \\
\text { presença de óleos e graxas provenientes de } \\
\text { barcos. }\end{array}$ \\
\hline
\end{tabular}

Fonte: adaptado de COSANPA (2000).

Ao lidar com jovens e adultos pertencentes a contextos sociais diferenciados dos encontrados em ambientes escolares convencionais, exigese para uma Educação voltada ao Processo de Gestão Ambiental a presença de profissionais habilitados para aplicar conhecimentos e metodologias específicas ao desenvolvimento de processos de ensino/aprendizagem a diferenciados segmentos da sociedade.

Ao se falar em Educação no Processo de Gestão Ambiental não está se falando de uma nova EA. Para Quintas (2004), está se falando em outra concepção de educação que toma o espaço da gestão ambiental como elemento estruturante na organização do processo de ensino/aprendizagem, construído com os sujeitos nele envolvidos, para que haja de fato controle social sobre decisões, as quais via de regra afetam o destino de muitos, senão de todos, destas e de futuras gerações.

Busca-se ir além de uma Educação Ambiental Formal ${ }^{3}$ e tenta-se utilizar as bases da Educação Ambiental Crítica que segundo (LAYRARGUES, 2002, apud, QUINTAS, 2004) é um processo educativo eminentemente político que visa ao desenvolvimento nos educandos de uma consciência crítica acerca das instituições, atores e fatores sociais geradores de riscos e respectivos conflitos socioambientais.

Políticas de EA deveriam ser, acima de tudo, um ato político voltado para a transformação social, com seu enfoque devendo buscar de acordo com Jacobi (2003), uma perspectiva de ação holística que relaciona o homem, a natureza e o universo, tendo como referência o esgotamento dos recursos naturais e que o principal responsável pela sua degradação é a sociedade em diferentes níveis e graus.

Apreende-se, no entanto, que é precisamente na esfera local onde conceitos tão abstratos, como por exemplo, o conceito de desenvolvimento sustentável pode tomar um significado real e adaptado às condições de cada contexto social (GÓMEZ, 2001). ${ }^{3}$ Nesta concepção, o elemento estruturante da sua prática pedagógica é o funcionamento dos
sistemas ecológicos.

Revbea, Rio Grande, V. 8, № 1:50-67, 2013. 
No decorrer do trabalho foi verificado que alterações na qualidade ambiental no lago Bolonha são decorrentes da ação antrópica em virtude do lançamento de resíduos domésticos em córregos que (direta ou indiretamente) tem suas desembocaduras no referido lago, bem como de substâncias trazidas pelo duto de captação de água, o qual está conectado ao lago Água Preta que por sua vez abastece o lago Bolonha, água está que tem sua origem do Rio Guamá.

A água que abastece a RMB é proveniente do lago Bolonha a qual é tratada na Estação de Tratamento de Água (ETA). Porém, é importante destacar que boa parte da população residente na RMB desconhece a proveniência da água consumida em seus domicílios, mesmo aquelas populações que moram as proximidades da APA.

Tal desconhecimento leva populações residentes no entorno da APA a depositar resíduos sólidos ou escoar seus efluentes domésticos as proximidades de córregos, e este material acaba por ser carreado para os principais cursos d'água. No entanto, este desconhecimento não deveria ocorrer.

O Poder Público estadual, transfigurado na Secretaria Estadual de Meio Ambiente (SEMA), deveria orientar a população a conviver com o ambiente que está "a suas portas", no intuito de apresentá-los a APA (visto estar sob sua jurisdição), bem como clarificar as populações residentes nesse entorno 0 papel desempenhado pela APA, como ela se constitui e por último, mas não menos importante, quem tem o papel de preservá-la.

Inserindo a população no contexto da APA, acredita-se ser possível propiciar novas atitudes e comportamentos, assim como estimular a mudança de valores individuais e coletivos (JACOBI, 1997). Para o alcance de tal objetivo há necessidade de um pensamento crítico da EA e a definição de um posicionamento ético-político, situando o ambiente conceitual e político onde a EA pode buscar sua fundamentação enquanto projeto educativo que pretende transformar a sociedade (CARVALHO, 2004).

Para se ter uma visão mais clara da vertente crítica (emancipatória) da EA, faz-se um contraponto com as ideias da visão conservadora no Quadro 3.

A visão emancipatória (crítica) representa para a dimensão ambiental a possibilidade de lidar com conexões entre diferentes dimensões humanas, possibilitando entrelaçamentos e trocas entre múltiplos saberes. Assim para Jacobi (2005), o entendimento sobre os problemas ambientais se dá por meio da visão do meio ambiente como um campo de conhecimento e significados socialmente construídos, que é perpassado pela diversidade cultural e ideológica e pelos conflitos de interesse. 
Quadro 3: Eixos para o discurso da educação ambiental

\begin{tabular}{|c|c|}
\hline VISÃO CONSERVADORA & VISÃO EMANCIPATÓRIA \\
\hline Visão reformista; & $\begin{array}{l}\text { Referenciais no campo do pensamento } \\
\text { crítico; }\end{array}$ \\
\hline Propõe respostas instrumentais; & Educação baseada em práticas; \\
\hline \multirow[t]{4}{*}{$\begin{array}{l}\text { Ações pontuais, descontextualizadas dos } \\
\text { temas geradores, freqüentemente } \\
\text { descoladas de uma proposta pedagógica, } \\
\text { sem questionar o padrão civilizatório, } \\
\text { apenas realimentando uma visão } \\
\text { simplista e reducionista; }\end{array}$} & $\begin{array}{l}\text { Orientações e e conteúdos que } \\
\text { transcendem a preservação ambiental; }\end{array}$ \\
\hline & $\begin{array}{l}\text { Precisa construir um instrumental que } \\
\text { promova uma atitude crítica; }\end{array}$ \\
\hline & $\begin{array}{l}\text { Construir uma compreensão complexa e } \\
\text { a politização da problemática ambiental; }\end{array}$ \\
\hline & $\begin{array}{l}\text { Participação dos sujeitos, o que explicita } \\
\text { uma ênfase em práticas sociais menos } \\
\text { rígidas, centradas na cooperação entre } \\
\text { os atores. }\end{array}$ \\
\hline
\end{tabular}

Fonte: Baseado em Lima (2002) e Loureiro (2004, apud JACOBI, 2005).

Esta abordagem busca superar o reducionismo e estimula um pensar e fazer sobre o meio ambiente diretamente vinculado ao diálogo entre saberes, à participação, aos valores éticos como valores fundamentais para fortalecer a complexa interação entre sociedade e natureza (JACOBI, 2005). Nesse sentido, o papel dos educadores é essencial para impulsionar as transformações de uma educação que assume um compromisso com 0 desenvolvimento sustentável e também com as futuras gerações.

Jacobi (2005) continua dizendo que a inserção da EA numa perspectiva crítica ocorre na medida em que o professor-educador assume uma postura reflexiva. Talvez esta seja uma das maiores tarefas no concernente a efetiva implementação de políticas de EA consistentes, as quais venham a de fato atingir o meio educacional formal e o não-formal.

Tristão (2002) observa que existem quatro desafios da EA (Quadro 4), os quais entrelaçados, estão associados ao papel do educador na contemporaneidade. 
Quadro 4: Desafios da EA associados ao papel do educador na contemporaneidade.

\begin{tabular}{|c|l|}
\hline PRIMEIRO DESAFIO & $\begin{array}{l}\text { Enfrentar a multiplicidade de visões, e isto } \\
\text { implica a preparação do educador para fazer } \\
\text { as conexões e articular os processos } \\
\text { cognitivos com os contextos da vida. }\end{array}$ \\
\hline SEGUNDO DESAFIO & \begin{tabular}{l} 
Superar a visão do "especialista". \\
\hline TERCEIRO DESAFIO
\end{tabular} \\
\hline QUARTO DESAFIO & $\begin{array}{l}\text { Superar a "pedagogia das certezas", e isto } \\
\text { converge com as premissas que norteiam a } \\
\text { formação do "professor reflexivo". }\end{array}$ \\
\hline $\begin{array}{l}\text { Superar a lógica da exclusão, que soma ao } \\
\text { desafio da sustentabilidade a necessidade da } \\
\text { superação das desigualdades sociais. }\end{array}$ \\
\hline
\end{tabular}

Fonte: adaptado de Tristão (2002).

$\mathrm{Na}$ roda destes desafios, pensa-se também ser importante o papel da disciplinaridade anterior ao da interdisciplinaridade, uma vez que qualquer profissional envolvido com educação deve estar ciente de seu papel enquanto educador, formador de indivíduos. No caso da Geografia, a título de exemplo, o profissional habilitado deve (ou deveria) ter plena consciência de como a ciência geográfica poderá contribuir para a formação de indivíduos críticos enquanto agentes sociais dotados de conhecimentos suficientes para que uma boa leitura da realidade possa ser processada e este assim consiga agir de forma coerente e consciente para com os fenômenos que se desenvolvem e o afetam direta e/ou indiretamente.

Acredita-se que a combinação de várias áreas de conhecimento, formadoras da conhecida interdisciplinaridade se torna possível mediante a articulação consciente de práticas educativas aplicadas por cada profissionaleducador nas mais diferentes ciências (história, geografia, biologia, matemática, etc), não sendo suficiente a mera reunião de diferentes disciplinas para o exercício interdisciplinar.

Para o lago Bolonha, tem-se como premissas que a EA deve se apoiar em trocas sistemáticas e no confronto de saberes disciplinares e não disciplinares que incluam não apenas uma problemática nas interfaces entre as diversas ciências naturais e sociais, mas também o conhecimento dos agentes que compõem a RMB, para que assim venham a ocorrer mudanças efetivas na APA Belém. 


\section{AÇÕES EDUCATIVAS E O LAGO BOLONHA: PROPOSTAS DE EDUCAÇÃO AMBIENTAL}

O Parque Ambiental de Belém (PAB) ${ }^{4}$ localizado na Área de Proteção Ambiental de Belém (APA Belém), segundo o Art. $3^{\circ}$ do Decreto Estadual $n^{\circ}$ 1.552 de 03 de maio de 1993, tem dentre seus objetivos principais os seguintes:

1. Propiciar um espaço de lazer para a comunidade, bem como possibilitar o desenvolvimento de atividades científicas, culturais, educativas, turísticas e recreativas;

2. Assegurar a potabilidade da água, através do manejo dos mananciais e da recuperação das áreas degradadas;

3. Ampliar a vida útil dos lagos Bolonha e Água Preta;

Diversas foram as medidas ${ }^{5}$ para ampliar a vida útil dos lagos Bolonha e Água Preta por parte do Poder Público. Isso se deve ao fato de serem as reconhecidas principais fontes viáveis (a médio e longo prazo) de abastecimento de água da RMB, com o intuito principal de assegurar a potabilidade da água mediante seu armazenamento e posterior tratamento otimizando o abastecimento.

As medidas tomadas entram em consonância com o parágrafo primeiro do artigo 225 da Constituição Federal de 1988. No entanto, a criação de condições para coletividade cumprir o seu dever de defender e proteger "o meio ambiente ecologicamente equilibrado para as presentes e futuras gerações", por meio da promoção da EA na APA Belém vem sendo em certa medida negligenciada pelo Poder Público.

Segundo o Plano de Interpretação Ambiental do Parque Ambiental de Belém desenvolvido pelo governo do estado no ano de 1999, realizado a partir do inventário dos recursos do Parque, bem como de sua situação contextual, foram analisados e assim estabelecidos os seguintes objetivos:

a) Levar o visitante e o público em geral a uma tomada de consciência de seu papel dentro do processo dinâmico da natureza;

b) Conscientizar o visitante e o público em geral sobre os benefícios oriundos da preservação dos recursos naturais;

c) Incentivar o visitante e o público em geral ao conhecimento, a valorização, ao uso e ao desfrute dos recursos do Parque, a fim de que os compreenda e aprecie;

\footnotetext{
${ }^{4}$ Nos dias de hoje o parque localizado dentro da APA Belém recebe o nome de Parque Estadual do Utinga.

${ }^{5}$ Utilização dos lagos para abastecimento, ampliação do sistema de captação, criação da APA, aumento da vazão para suprir a demanda, etc. Mais informações podem ser encontradas em Araújo Jr. (2010).
} 
d) Contribuir para a redução do impacto da visitação sobre a área e garantir a segurança dos visitantes, mediante um adequado fluxo e sua melhor distribuição;

e) Mostrar ao visitante e ao público em geral o papel do Parque, de seus objetivos e do uso de seus recursos;

f) Levar à população do município, notadamente do entorno, o conhecimento da importância do Parque para o mesmo;

Os aspectos expostos revelam que medidas são pensadas pelo Poder Público para otimizar a utilização da APA Belém em termos de Parque Ambiental, porém se percebe que ações concretas não são tomadas para essa efetivação.

Uma sugestão seria a programação interpretativa, a qual visasse por meio de alguns aspectos específicos do PAB demonstrar a relevância da APA para a população como um todo.

Através da caracterização da APA Belém como uma Bacia Hidrográfica, por exemplo, buscar-se-ia levar ao visitante a visualização da formação topográfica que o PAB apresenta e que o caracteriza como uma bacia hidrográfica. Igualmente o seu papel para o abastecimento de água da cidade. Neste tema, podem-se explorar com profundidade as consequências da ação antrópica, especialmente da população do entorno do Parque, na qualidade da água dos lagos que abastecem Belém.

Topograficamente falando, seria possível mostrar, principalmente à população residente as proximidades do lagos Bolonha e Água Preta que as residências localizadas em cotas altas para a APA (até 10 metros), em conjunto com a retirada da cobertura vegetal potencializam o escoamento superficial facilitando o carreamento de detritos para os rios e igarapés que formam a bacia hidrográfica em questão, degradando assim o sistema hídrico.

Aspectos como a mineralização da água, decomposição da camada florestal, regeneração natural das florestas, sucessão e estrutura das matas do Parque, fluxo de energia (cadeia alimentar, ciclo da água, clima), dinâmica da fauna silvestre, entre outros, devem (ou deveriam) ser abordados, pois os processos naturais são acontecimentos dinâmicos que "movimentam" as características físico-químicas da natureza.

Além da elucidação dos aspectos mais naturais presentes na APA Belém, os quais sem dúvida envolvem a relação indissociável sociedadenatureza, há de se destacar também para os visitantes e mesmo moradores da área um monumento vivo da história e da cultura paraenses, o qual se encontra em meio às matas da EMBRAPA, na estrada da Ceasa, são as ruínas do Murutucu (Figuras 3 e 4), um dos palcos principais da Cabanagem (1835 1840), revolta popular na então província do Grão-Pará, alimentada pelo desejo de independência política em reação à extrema miséria da maioria da população paraense. 

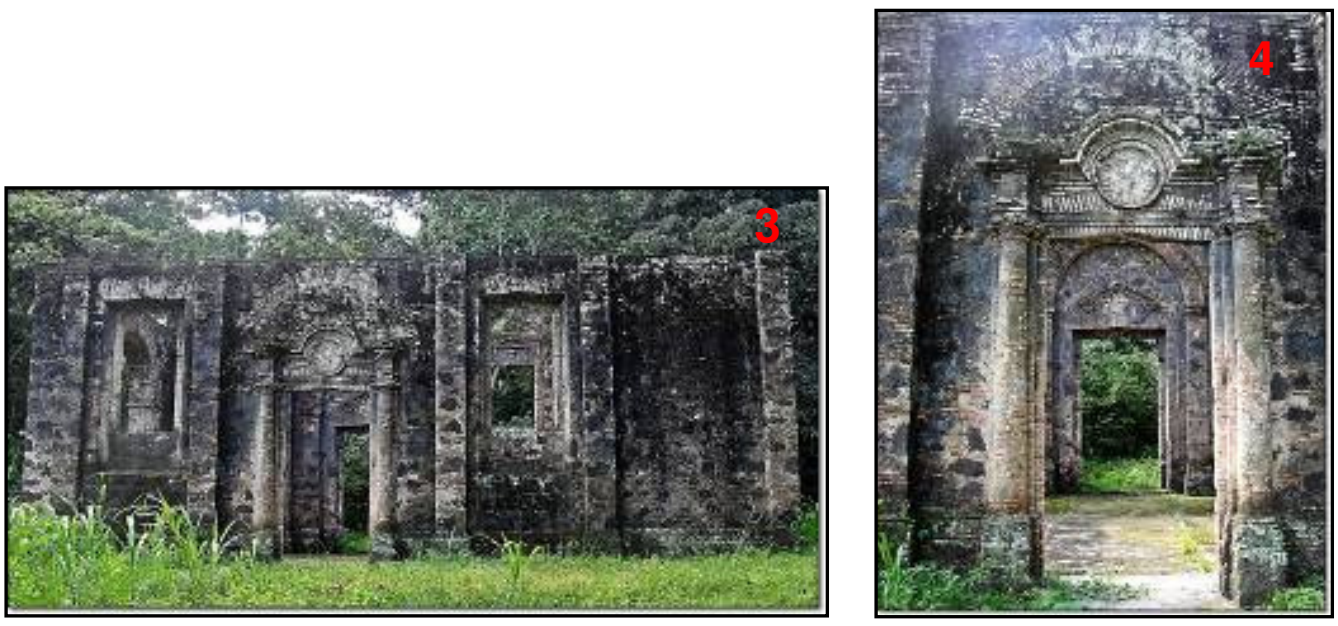

Figuras 3 e 4: Ruínas do antigo engenho do Murutucu, hoje "abandonado" no interior do Parque Estadual do Utinga.

Desde 1940, o Murutucu é propriedade da União e hoje pertence à área da EMBRAPA. O governo federal implantou no local um campo experimental de prática agrícola e foi isso que garantiu a preservação, em parte, dos elementos do sítio. Acredita-se que por ser um patrimônio tombado pelo Instituto do Patrimônio Histórico e Artístico Nacional - IPHAN há possibilidade de autogestão e transformação em um espaço de educação e turismo.

Para tanto haveria necessidade do Poder Público por meio de políticas afirmativas de revitalização desse importante espaço se comprometer em reerguê-lo, propiciando as comunidades da APA Belém, da RMB e turistas, um legítimo espaço de aprendizagem não-formal (além dos muros da escola), com o intuito de potencializar a preservação das áreas de mata, as quais também são um patrimônio que muitas vezes é dissociado da realidade "urbana" de Belém.

Morin (1997) afirma que nossa educação nos ensinou a separar e a isolar as coisas. Separamos os objetos de seus contextos, separamos a realidade em disciplinas compartimentadas umas das outras. Mas, como a realidade é feita de laços e interações, nosso conhecimento é incapaz de perceber o complexus, o tecido que junto o todo.

Não é suficiente mostrar a população residente no entorno da APA Belém ou mesmo na RMB os elementos componentes desse espaço de forma dissociada da realidade delas, uma vez que conhecer é sempre rejuntar uma informação ao seu contexto e ao conjunto ao qual pertence (MORIN, 1997), além do que 0 atual cidadão necessita dessa compreensão da totalidade para se situar e ser eminentemente um agente social nesse mundo globalizado e complexificado (GUIMARÃES, 2000).

Como lembra Guimarães (2009) o ambiente como uma realidade 
realidade local e global, está no pátio escolar e na reserva ambiental, está no social e no ambiental, retomando os preceitos da Educação Ambiental Crítica.

Para essa proposta crítica, os problemas ambientais são "temas geradores" que problematizam a realidade para compreendê-la, subsidiando para uma ação crítica sujeitos em processo de conscientização. Para Morin (2000) o dever principal da educação é armar cada indivíduo para um combate vital rumo à lucidez.

A Educação Ambiental Crítica volta-se para uma práxis de intervenção em uma realidade complexa; é coletiva; seu conteúdo está para além dos livros, está na realidade social e ambiental derrubando os muros das escolas.

Para além de uma educação presa ao conteúdo dos livros sem alguma ligação com a realidade social ou ambiental, podendo ficar restrita à sala de aula ou a uma reserva ecológica, não estimulando a interação dos indivíduos em um processo de intervenção crítica, uma educação, portanto, "bancária", conservadora, pouco apta a transformações sociais, conforme Freire (1992a) concorre-se para uma educação voltada para a transformação da sociedade, por meio de uma "Pedagogia da Esperança" capaz de construir utopias, como um "inédito viável", por aqueles que têm a firmeza da renúncia e a coragem de inovar (FREIRE, 1992b), aqueles que têm a possibilidade de construir uma sociedade melhor.

Há de se deixar claro que para haver mudanças significativas não bastam apenas transformações individuais (partes), mas se necessita também de transformações recíprocas na sociedade (todo), na busca pelo equilíbrio social e ambiental.

Bordalo (2006) destaca que entre os anos de 1984-2004 diversas foram às medidas jurídico-políticas criadas com o intuito de proteger a principal fonte de abastecimento hídrico da RMB, no entanto, as ações implementadas não foram eficazes, pois durante a implementação dessas políticas a descentralização das ações entre estado e município não ocorreu de fato, bem como, houve apenas uma tímida participação dos usuários e das entidades da sociedade civil com sede e atuação comprovada na área dos mananciais.

Lançando mão da teoria geral dos sistemas, recomenda-se ao poder público considerar o sistema ambiental Bolonha e Água Preta, situados na APA-Belém como formações "naturais", experimentando sob certa forma, o impacto dos ambientes social, econômico e tecnogênico (SOTCHAVA, 1977).

Tal recomendação se processa por ser sabido que dos seus $100 \%$ de capacidade $80 \%$ são oriundos de captação ${ }^{6}$ do Rio Guamá (porção sul da $\mathrm{RMB}$ ) e circunscrições, os $20 \%$ restantes advém de precipitações. De posse desta informação não se torna recomendado considerar o todo (APA-Belém) como somente a soma das partes (captação, precipitação, influência antrópica,

\footnotetext{
6 Informação obtida em visita monitorada a Área de Proteção Ambiental de Belém - APABelém, no dia 29 de maio de 2010.
}

revista brasileira 
etc.), mas como dependente da intensidade das interações e inter-relações que ocorrem entre as partes.

Coadunando com as ideias de Limberger (2006), para compreender as características das partes constitutivas de um sistema é necessário que se conheça não somente as partes, mas também as suas relações.

As partes só podem ser entendidas através do todo maior, portanto as propriedades do sistema são destruídas quando um sistema tem seus elementos isolados, separados e segundo Capra (1996) não existe parte: o que se denomina parte "é apenas um padrão numa teia inseparável de relações".

\section{CONSIDERAÇÕES}

Gerir recursos hídricos requer conhecimento e participação, com o entrelaçamento destas variáveis ao se limitar um o desenvolvimento completo é comprometido. Esforços no sentido de desenvolvê-los de forma articulada levam a um efeito sinérgico, de modo que o efeito positivo é potencializado.

Sobre a degradação ambiental dos mananciais do Utinga, vários estudos realizados na RMB mostram que vem ocorrendo uma diminuição na área de cobertura vegetal original nos mananciais causada diretamente pelo desmatamento da mata ciliar decorrente: da expansão da área urbana, da exploração de material para construção civil, da implantação de cemitérios (Recanto da Saudade) e do Complexo de Destino Final de Resíduos Sólidos da RMB (lixão do Aurá).

O avanço do desmatamento na área das matas do Utinga traz consigo uma grande preocupação no sentido da preservação da grande biodiversidade encontrada nessas matas, bem como na diminuição da proteção contra a erosão superficial, a qual acarreta o aumento do assoreamento das margens e cabeceiras dos lagos.

A alta ocorrência de macrófitas $^{7}$ no lago Bolonha evidencia a concentração de nutrientes propiciadores à sua proliferação, os quais comprometem a rede de abastecimento hídrico, uma vez que a decomposição de matéria orgânica ocasiona a desoxigenação da água, tornando-a menos adequada a ingestão humana, pois está agora passa a ser composta por outras substâncias que em excesso podem comprometer seus consumidores.

A retirada desse tipo de vegetação ajuda o sistema a recuperar 0 "fôlego", minimizando o impacto causado pela ocorrência do processo de eutrofização artificial (desoxigenação da água, aumento da concentração de gases nocivos, etc.). Porém, está ação torna-se sem efeito na medida em que o poder público, responsável por tal medida mitigadora, não atue em um dos

\footnotetext{
7 Plantas aquáticas que vivem em brejos até ambientes verdadeiramente aquáticos (incluindo os corpos de água doce, salobra e salgada). São caracterizados como vegetais que durante sua evolução retornaram do ambiente terrestre para o aquático.
} 
cernes do problema (o qual não somente é ambiental, com também social), os agentes sociais, consumidores e degradadores do sistema.

Cogita-se que uma das possíveis razões para a qual isso não venha a público seja o fato de se considerar o homem como externo a questão ambiental, ou seja, sujeito irrelevante no tocante a temática ambiental, a qual está intrinsecamente ligada a qualidade de vida no sentido latu da expressão.

Considerar a sociedade como agente ativo no processo de produção e manutenção do ambiente natural é ímpar e possível por meio de ações educativas - para além do trabalho em sala de aula (ensino formal).

A Área de Proteção Ambiental de Belém (APA-Belém) é potencialmente campo de execução de ações educativas formais e não-formais de uso e conservação dos recursos naturais. Mas para que isso de fato venha a ocorrer torna-se necessário que haja envolvimento de agentes institucionais (Estado e Município) e da sociedade civil (moradores, estudantes, turistas, etc.) em um amplo processo de conscientização e educação ambiental no bojo da sociedade.

Propostas de caracterização física e social só terão efeito se demonstrado que não somente agentes institucionais tem a responsabilidade de manter as fontes de recurso hídrico da cidade, atribuindo à sociedade civil, também, este encargo colocando-a como agente impactante e modificador do sistema natural.

Pode-se considerar então que a APA-Belém sendo tratada a luz das atribuições do sistemismo conseguiria avançar em termos de recuperação ambiental, principalmente no Lago Bolonha, bem como considerar os agentes sociais do entorno como parte importante deste sistema, criando não só medidas direcionadas ao Lago, como também as comunidades do entorno, possivelmente criando programas de Educação Ambiental para mostrar as consequências do uso irracional de recursos a médio e longo prazo, pregando que um ser vivo não é definido apenas por sua constituição, mas também por meio de sua organização.

\section{REFERÊNCIAS}

ARAÚJO Jr., A.C.R. O lago Bolonha no contexto da Região Metropolitana de Belém (RMB) - Pará: abastecimento, qualidade ambiental e ações educativas. 2010, 89 f. Trabalho de Conclusão de Curso (Faculdade de Geografia e Cartografia). IFCH/UFPA, Belém-PA, 2010.

BORDALO, C.A.L. O desafio das águas numa metrópole amazônida: uma reflexão das políticas de proteção dos mananciais da Região Metropolitana de Belém-PA (1984 - 2004). 2006, 369 f. Tese de Doutorado (Programa de PósGraduação em Desenvolvimento Sustentável do Trópico Úmido). NUMA/UFPA, Belém, 2006.

CAPRA, F. A teia da vida. São Paulo: Cultrix, 1996. 
CARVALHO, I.C.M. Educação Ambiental Crítica: nomes e endereçamentos da educação. In: MMA/ Secretaria Executiva/ Diretoria de Educação Ambiental (Org.). Identidades da educação ambiental brasileira. Brasília: MMA, 2004.

COSANPA, Urbanização e medidas de proteção sanitária da região dos lagos Utinga. Relatório técnico 023, 2000.

FEITOSA, D. Macrodrenagem e Água Potável em Belém do Pará. Documentário Histórico - Cosanpa. Belém, Multsoft, 1994.

FREIRE, P. Pedagogia da Esperança. Rio de Janeiro: Paz e Terra, 1992a.

FREIRE, P. Pedagogia do Oprimido. 20aㅡ ed. Rio de Janeiro: Paz e Terra, $1992 b$.

GÓMEZ, J.A.C. La educación ambiental en el desarrollo humano: horizontes para la sustentabilidad ecológica y la responsabilidad social. Revista Investigación en la Escuela, n. 45 de 2001.

GUIMARÃES, M. Educação ambiental: temas em meio ambiente. Editora Unigranrio, Duque de Caxias, 2000.

GUIMARÃES, M. Sustentabilidade e Educação Ambiental. In: CUNHA, S. B. da e GUERRA, A. J. T. (Orgs.). A questão ambiental: diferentes abordagens. $5^{\text {a }}$ ed. Rio de Janeiro: Bertrand Brasil, 2009.

IBAMA. Diretrizes para operacionalização do Programa Nacional de Educação Ambiental. Brasília: Edições IBAMA, 1995 (Série Meio Ambiente em Debate 9).

JACOBI, P. Meio ambiente urbano e sustentabilidade: alguns elementos para a reflexão. In: CAVALCANTI, C. (Org.). Meio ambiente, desenvolvimento sustentável e políticas públicas. São Paulo: Cortez Editora, 1997.

JACOBI, P.R. Educação ambiental, cidadania e sustentabilidade. Cad. Pesqui. [online]. 2003, n.118, pp. 189-206.

JACOBI, P.R. Educação Ambiental: o desafio da construção de um pensamento crítico, complexo e reflexivo. Educ. Pesqui. vol. 31, no. 2. São Paulo. May/Aug. 2005.

LAYRARGUES, P.P. Apresentação: (Re)Conhecendo a educação ambiental brasileira. In: MMA/ Secretaria Executiva/ Diretoria de Educação Ambiental (Org.).Identidades da educação ambiental brasileira. Brasília: MMA, 2004.

LIMBERGER, L. Abordagem sistêmica e complexidade na geografia. Geografia - v. 15, n. 2, jul/dez, 2006. Disponível em <http://www.uel.br/revistas/geografias, acesso em 15 de abril de 2010

MORIN, E. Complexidade e ética da solidariedade. In: CASTRO, G. de; CARVALHO, E. de A.; ALMEIDA, M. C. de (Coord.). Ensaios de Complexidade. Porto Alegre, Sulina, 1997.

MORIN, E. Saberes globais e saberes locais: o olhar transdisciplinar. Rio de Janeiro, Garamond, 2000.

Revbea, Rio Grande, V. 8, № 1:50-67, 2013. 
NASCIMENTO, C.C. Clima e morfologia urbana em Belém. Universidade Federal do Pará. Núcleo de Meio Ambiente. 1995.

PAIVA, R. et. al. A ocupação urbana como fonte poluidora dos corpos d'água na Região Amazônica. Estudo de caso: composição e biomassa primária da foz do igarapé Tucunduba (Belém-Pará). In: UHLY, S.; SOUZA, E.L. (orgs.). A questão da água na grande Belém. UFPA: Casa de Estudos Germânicos. Fundação Heinrich Böll. 2004.

PARÁ. DECRETO no 1.551 e no 1.552, de 03 de maio de 1993. Dispõe sobre a Implantação da Área de Proteção Ambiental dos Mananciais de Abastecimento de Água de Belém - APA Belém.

PARÁ. SECTAM. Parque Ambiental de Belém: plano de interpretação ambiental. Belém, 1999.

PEREIRA, J.A.; MENDES, F. Sistema de Esgotamento Sanitário. In: PEREIRA, J.A. (org). Saneamento Ambiental em Áreas Urbanas. Esgotamento Sanitário na Região Metropolitana de Belém. UFPA/NUMA. Belém, 2003.

QUINTAS, J.S. Educação no Processo de Gestão Ambiental: Uma Proposta de Educação Ambiental Transformadora e Emancipatória. In: MMA/ Secretaria Executiva/ Diretoria de Educação Ambiental (Org.). Identidades da educação ambiental brasileira. Brasília: MMA, 2004.

SODRÉ, S.S.V. Hidroquímica dos lagos Bolonha e Água Preta mananciais de Belém-Pará. Dissertação (Mestrado em Ciências Ambientais) - Programa de Pós-Graduação em Ciências Ambientais, Instituto de Geociências, Universidade Federal do Pará, Museu Paraense Emílio Goeldi e EMBRAPA, Belém, 2007.

SOTCHAVA, V.B.O estudo dos Geossistemas. Métodos em Questão, ㄲo 16. IG, USP, São Paulo, 1977.

TRISTÃO, M. As dimensões e os desafios da educação ambiental na sociedade do conhecimento. In: RUSHEINSKY, A. (Org.). Educação ambiental: abordagens múltiplas. Porto Alegre: Artmed, 2002. p. 173-181. 